\title{
Distribution, Morphology, and Natural History of the Medo Pit Viper, Viridovipera medoensis (Viperidae, Crotalinae) in Arunachal Pradesh, Northeastern India
}

\author{
Rowland Griffin ${ }^{1}$, Gerard Martin², Romulus Whitaker ${ }^{3}$, and Todd R. Lewis ${ }^{4}$ \\ ${ }^{1}$ Brooklea, John Beales Hill, Pilton, BA4 4DB, UK. (rowland_griffin@yahoo.co.uk) \\ ${ }^{2}$ The Gerry Martin Project, 33 Carmelaram Post, Chikkabelandur, Sarjapar Road, Bangalore - 560 035, India \\ ${ }^{3}$ Pambukudivanam, Thiruvadisulam Village, Chengalpattu, Tamil Nadu, 603108, India \\ ${ }^{4}$ Westfield, 4 Worgret Road, Wareham, Dorset, BH20 4PJ, UK
}

Photographs by the senior author.

A sian pitvipers of the Trimeresurus complex comprise approximately 49 species. They are distributed throughout India, Indochina, China, the Philippines, and Indonesia. The systematics of the group has been confusing; many species are cryptic and almost indistinguishable to the naked eye (David et al. 2001a). In several recent revisions, the green pitvipers of the genus Trimeresurus were divided taxonomically based on a combination of morphological (hemipenal/ scalation) and molecular features. The accepted genera now include Cryptelytrops, Parias, Peltopelor, Popeia, Trimeresurus, Tropidolaemus, and Viridovipera (Malhotra and Thorpe 1997, 2000, 2004; Tu et al. 2000).

The Medo Pit Viper (Viridovipera medoensis Zhao in Zhao and Jiang 1977) is a nocturnal, arboreal pitviper that inhabits wet montane forests (David et al. 2001b). It was, until recently, only known from a restricted area comprising two localities from northern Myanmar, and the type locality in the Xizang Autonomous Region, China (Zhao and Adler 1993, David et al. 2001b). Recently, V. medoensis was reported from a single locality in Changlang District, Arunachal Pradesh (N27.440833, E96.915278) on the border with its known range in Myanmar (David et al. 2001b). Very little is known about the species' natural history due to its remote distribution and the political governance of land within its range. Viridovipera medoensis is listed as "data deficient" on the IUCN Red List of Threatened Species and is considered rare, with an "unknown" population trend (Zhou and Rao 2012).

Herein we report on the morphology, habitat, and behavior of Viridovipera medoensis encountered during a sur- vey for venomous snakes in Leporiang, Papum Pare District, Arunachal Pradesh (N27.22920, E093.33986; Fig. 1).

\section{Methods}

This study was conducted in two parts during April/May 2011 and August 2011. Nocturnal and diurnal visual encounter surveys (VES; McDiarmid et al. 2012) were conducted in targeted areas around Leporiang previously identified by local

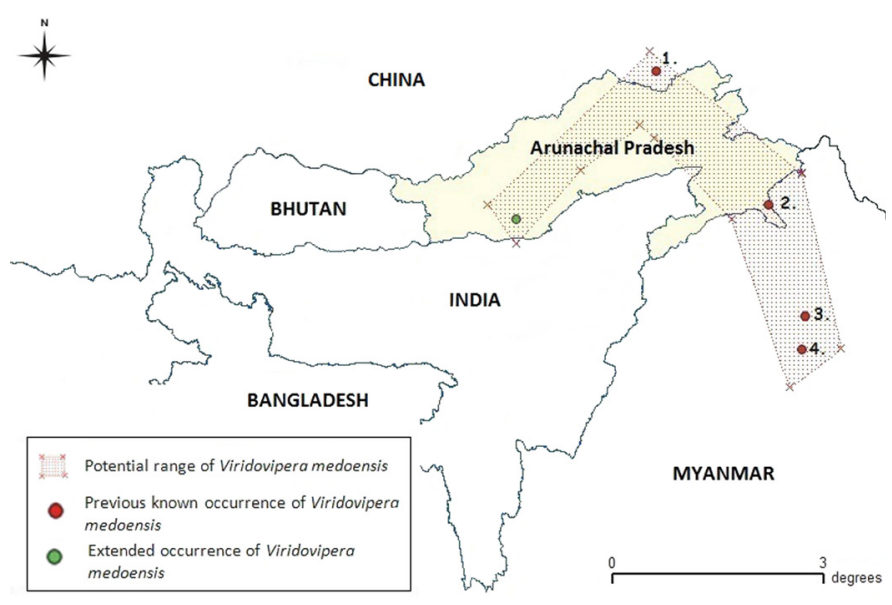

Fig. 1. Map showing actual locations and potential range of Viridovipera medoensis in northeastern India, China, and Myanmar. Red dots 1 to 4 indicate localities previously reported in David et al. (2001b); 1 = the type locality at Medog, Xizang Autonomous Region, China. (N 29.3252, E 95.3313). 2 = Gandhigram, Changlang District, Arunachal Pradesh, India (N 27.440833, E 96.915278). 3 = Nam Ti Valley, Kachin State, Myanmar (N 25.85388, E 97.4433). 4 = Myitkyina, Kachin State, Myanmar (N 25.3788, E 97.3880). Green dot = New records for Leporiang, Papum Pare District, Arunachal Pradesh, India (N 27.22920, E 093.33986). 


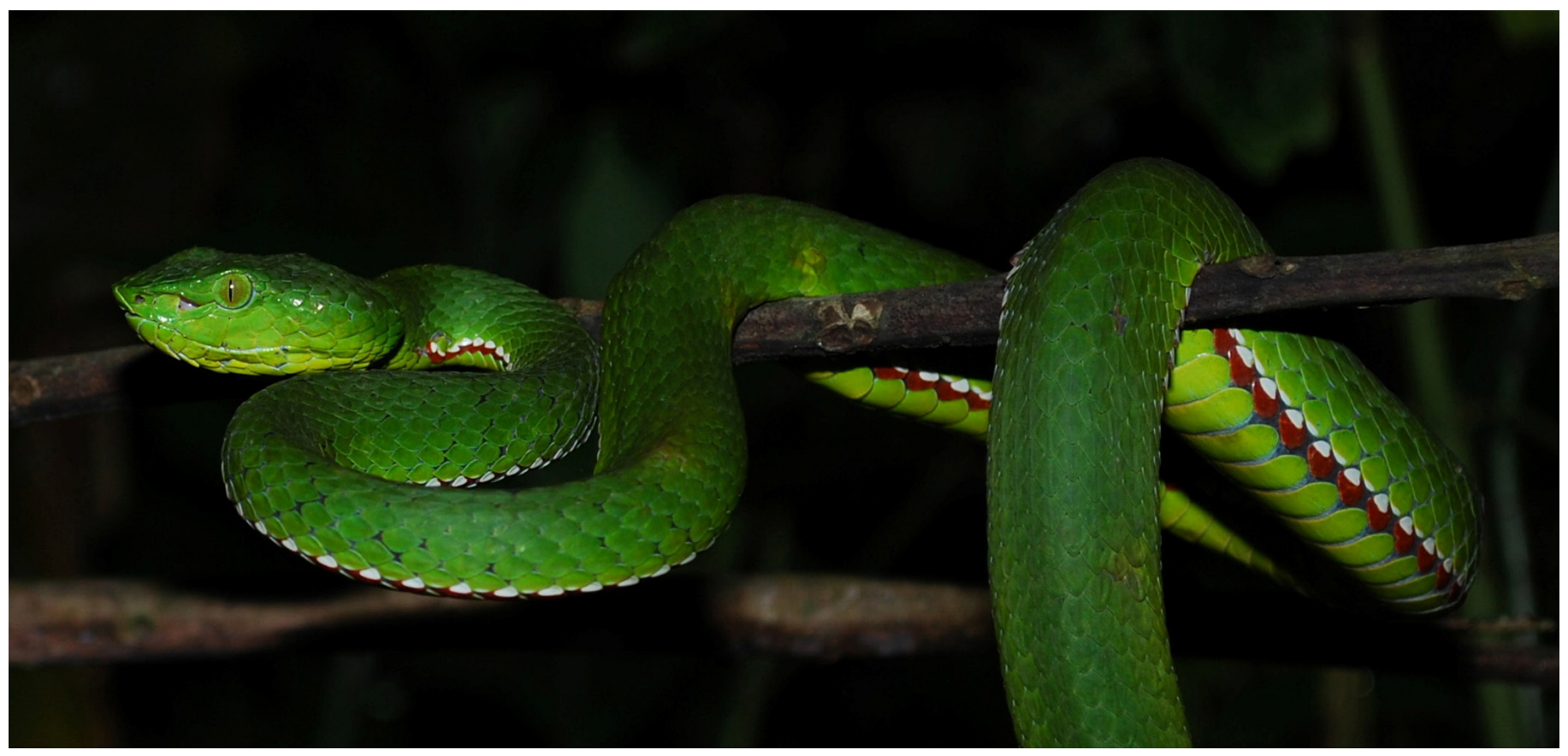

Fig. 2. A Medo Pit Viper (Viridovipera medoensis) in Papum Pare District, Arunachal Pradesh.

residents as having pitvipers. Data recorded included environmental conditions and morphometrics; weight (g), snout-vent length (SVL), total length (TL), sex, habitat, and perch height $(\mathrm{PH})$ when possible. Locations of individuals were recorded using a Garmin eTrex ${ }^{\mathrm{TM}}$ GPS and mapped using Quantum GIS Ver. 1.8.0.

Survey and morphometric measurements were carried out under research permits granted by the Arunachal Pradesh Forest Department. In the interest of conservation of the species, and despite a lack of preserved specimens in known collections globally, no specimens were collected. Spearman Rank correlation coefficients $\left(\mathrm{r}_{s}\right)$ were conducted in Statistica Ver. $7^{\mathrm{TM}}$ and MINITAB Ver. $16^{\mathrm{TM}}$ and were used to investigate morphological characteristics and habitat.

\section{Results and Discussion}

A total of 38 surveys were conducted over two periods (April/ May - 12 days; August - 10 days). Late April to early May is near the end of the wet season in the Papum Pare District of Arunachal Pradesh. August is considered a drier month.

Table 1. Morphometric data for the Medo Pit Viper (Viridovipera medoensis) at Leporiang, Papum Pare District, Arunachal Pradesh.

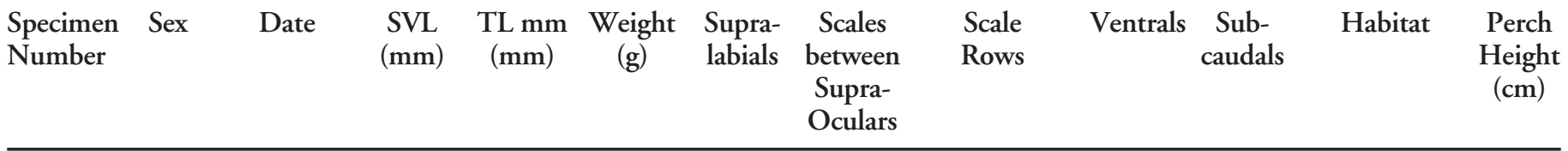

\begin{tabular}{lcccccccccccccccc} 
VM3 & Juv F & 30 Apr & 282 & 335 & 10 & - & - & 17 & - & River & 250 \\
\hline VM4 & Juv & 01 May & 217 & 262 & 5 & - & - & 17 & - & - & River & 50 \\
\hline VM2 & F & 02 May & 623 & 747 & - & 8 & - & $17: 17: 13$ & 142 & 53 & Riparian & 170 \\
\hline VM1 & M & 02 May & 484 & 627 & - & 8 & 9 & $17: 17: 13$ & 141 & 41 & Riparian & 100 \\
\hline J001 & F & 24 Aug & - & 582 & 70 & 9 & 9 & $17: 17: 13$ & 145 & 49 & Riparian & 200 \\
\hline R003 & F & 25 Aug & - & 673 & 60 & 8 & 12 & $17: 17: 13$ & 145 & 58 & Forest & 0 \\
\hline R004 & M & 25 Aug & 466 & 580 & 45 & 8 & 9 & $17: 17: 13$ & 146 & 61 & Road & 100 \\
\hline L002 & M & 26 Aug & 516 & 634 & 40 & 8 & 10 & $17: 17: 13$ & 141 & 58 & Agricultural & - \\
\hline L003 & F & 28 Aug & - & - & - & 9 & 10 & $17: 17: 13$ & 142 & 56 & Riparian & 152 \\
\hline
\end{tabular}




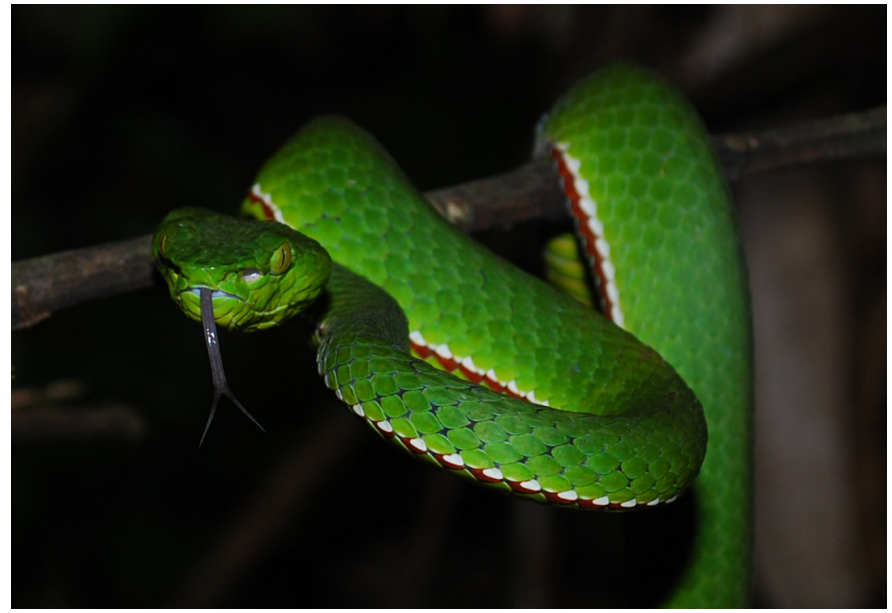

Fig. 3. A Medo Pit Viper (Viridovipera medoensis) in Papum Pare District, Arunachal Pradesh.

Temperature and humidity were recorded at the site of each encounter. Temperature was $22.8 \pm 4.17^{\circ} \mathrm{C}$ (range 18.9-27.2 ${ }^{\circ} \mathrm{C}$ ) and humidity $85.05 \pm 9.98 \% \mathrm{RH}$ (range $74.0-93.4 \%$ $\mathrm{RH})$. Weather at times of capture ranged from dry and warm to cloudy and overcast.
We encountered a total of nine Viridovipera medoensis, four adult females (J001, L003, R003, and VM2), three adult males (L002, R004, and L002), and two juveniles (VM3 [female] and VM4; Table 1 and Figs. 2-5). Two individuals (L002 and L003) were brought alive to our base camp by local villagers. All snakes were encountered at a mean altitude of $1131.8 \pm 84.1 \mathrm{~m}$ (range 1077-1312 m), concurrent with the elevational range reported by Whitaker and Captain (2004).

Snakes were identified by two morphological diagnostics: Scale rows 17:17:13 and nasal undivided and completely separated by a suture from the first supralabial (Leviton et al. 2003, Whitaker and Captain 2004). Hemipenial structure is also a diagnostic feature (Peng and Fuji 2000), but was not examined during this study. The cloacal scute was entire and subcaudals divided for all specimens. Only counts on midbody rows were recorded for juvenile identification due to the small size of the snakes and their potential susceptibility to stress during handling. The following mean scalation data were collected from the adults (Table 1): supralabials; males $8.0(\mathrm{n}=3)$ and females $8.5(\mathrm{n}=4)$ scales between supraoculars; males $9.33(\mathrm{n}=3)$ and females $8.5(\mathrm{n}=3)$ ventrals; males

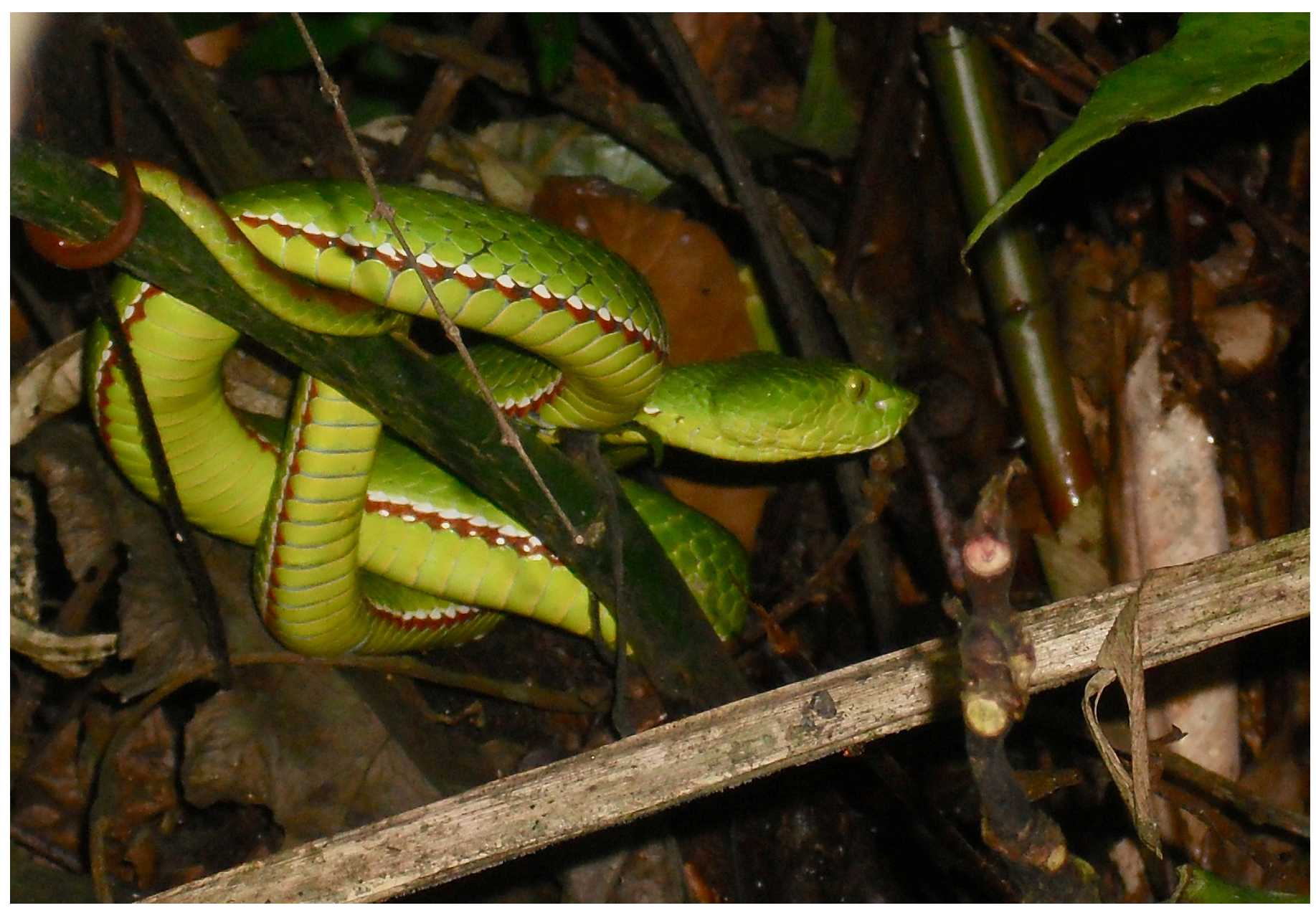

Fig. 4. A Medo Pit Viper (Viridovipera medoensis) in vegetation overhanging a small stream in Papum Pare District, Arunachal Pradesh. 


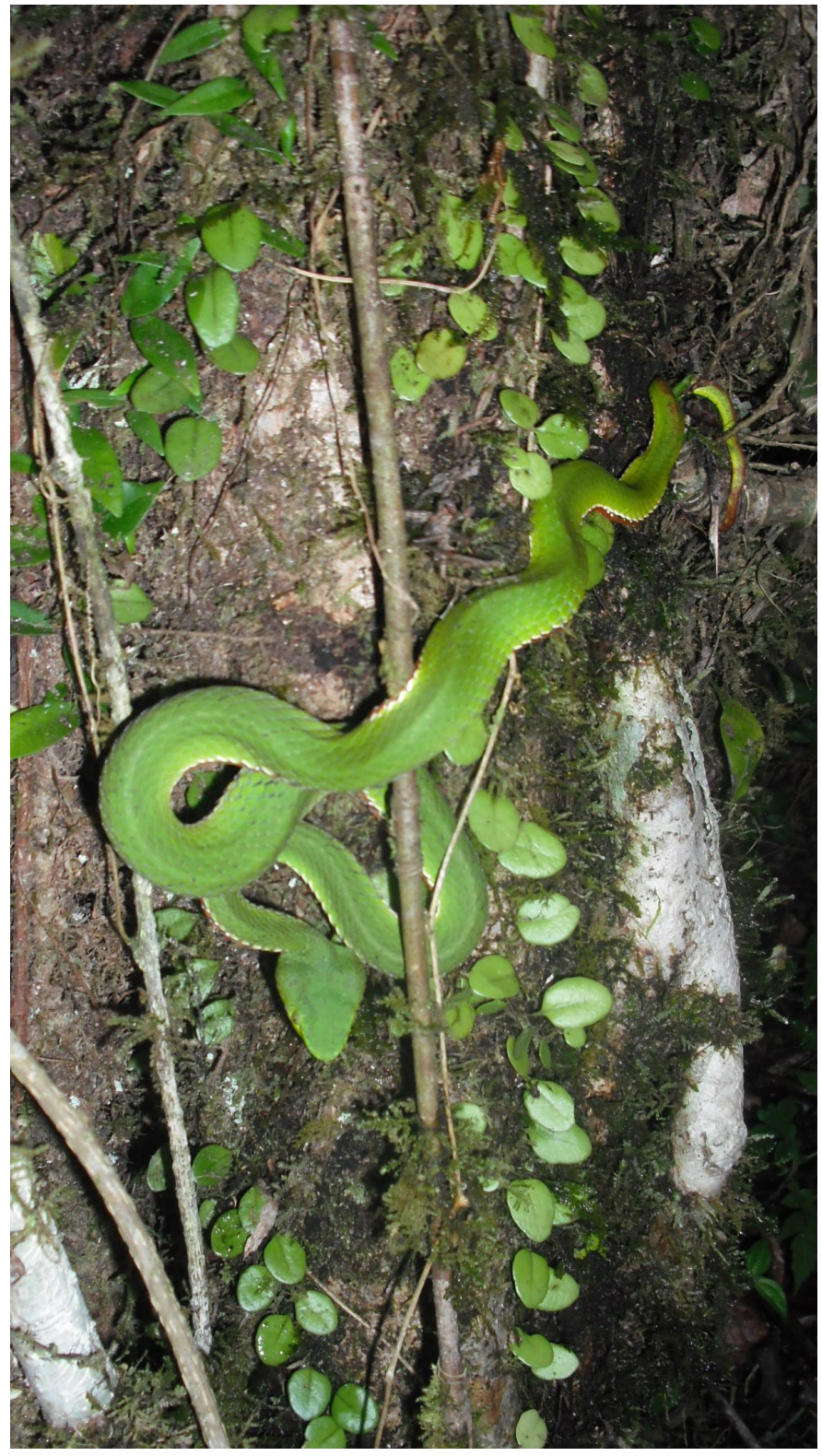

Fig. 5. A Medo Pit Viper (Viridovipera medoensis) in riparian habitat in Papum Pare District, Arunachal Pradesh.

$142.67(\mathrm{n}=3)$ and females $143.50(\mathrm{n}=4)$ subcaudals; males $53.33(\mathrm{n}=3)$ and females $54.00(\mathrm{n}=4)$.

Mean TL of males was $613.67 \mathrm{~mm}(\mathrm{n}=3)$, of females $667.33 \mathrm{~mm}(\mathrm{n}=3)$, and of juveniles $298.5(\mathrm{n}=2)$. Mean SVL of males was $488.67 \mathrm{~mm}(\mathrm{n}=3)$, of females $623.00 \mathrm{~mm}$ $(\mathrm{n}=1)$; and of juveniles $249.50 \mathrm{~mm}(\mathrm{n}=2)$. Mean weight of males was $42.50 \mathrm{~g}(\mathrm{n}=2)$, of females $65.00 \mathrm{~g}(\mathrm{n}=2)$, and of juveniles $7.50 \mathrm{~g}(\mathrm{n}=2)$ (Table 1 and Fig. 6). Female L003 weighed $140 \mathrm{~g}$ and was not included in these calculations due to the large meal she had ingested. The largest previously recorded Viridovipera medoensis was $677 \mathrm{~mm}$ (Whitaker and Captain 2004). Female VM2 measured in this study represents a new maximum length of $744 \mathrm{~mm}$ for the species.

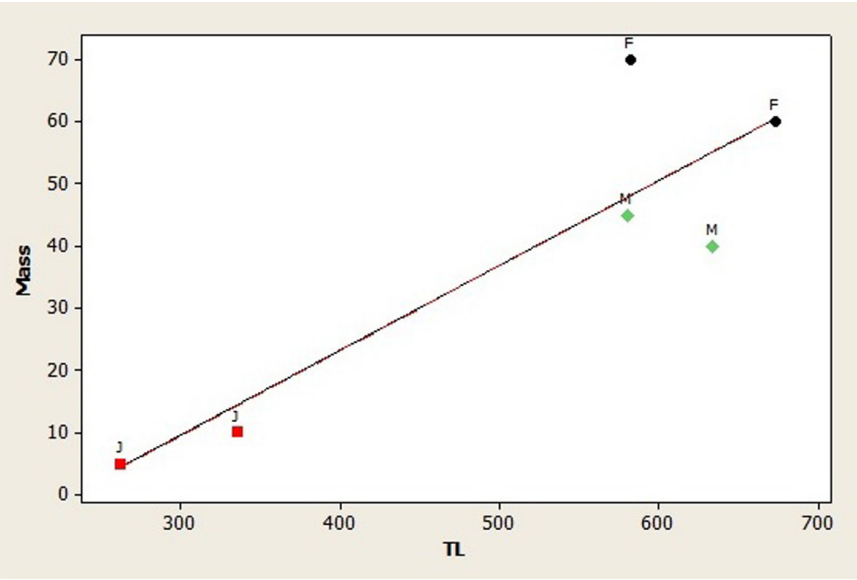

Fig. 6. Total length and mass of Medo Pit Vipers (Viridovipera medoensis) at Leporiang, Papum Pare District, Arunachal Pradesh.

Four of the snakes encountered during the survey were detected diurnally (1320-1445 h) and the other three nocturnally (1900-2030 h). Five were encountered perched between $0.5 \mathrm{~m}$ and $2.5 \mathrm{~m}$ on branches either next to or on paths near streams and rivers. No correlations between perch height, weight, and habitat were significant for any of the observations $\left(\mathrm{r}_{s}\right.$ range: $-0.226-0.714$, all $\left.\mathrm{P}>0.05\right)$, likely reflecting the small sample size. Two individuals, R003 and R004, were moving at the time of initial observation. R003 was moving on the ground in secondary deciduous forest $500 \mathrm{~m}$ on a slope above a nearby stream at $1320 \mathrm{~h}$. It subsequently moved rapidly downhill to evade capture at which point it attempted to conceal itself in leaf litter. When it detected our presence, it climbed the nearest tree to a branch at a height of $1.75 \mathrm{~m}$ above the ground before being captured. This escape evasion behavior was an interesting and swift response for a traditionally arboreal species. Similar escape behaviour by Trimeresurus malabaricus in the Western Ghats has been postulated to be in response to predation by King Cobras (Ophiophagus hannah; R. Whitaker pers. comm.).

Viridovipera medoensis has been reported to have a strong association with bamboo (Bambusa spp.) stands, and in Arunachal Pradesh, has been found hibernating in upright dead bamboo (David et al. 2001b, Leviton et al. 2003, Whitaker and Captain 2004). This study confirms a range of habitat usage for $V$. medoensis that includes forest and riparian vegetation alongside streams and rivers (Figs. 7 and 8). Interestingly, R004 was discovered in a tree on an embankment alongside a main road between Leporiang and the nearby town of Sagalee, suggesting that the species can be found in secondary and human-altered environments as well as in natural areas.

Our new records of Viridovipera medoensis are an important finding and represent a significant range extension of 


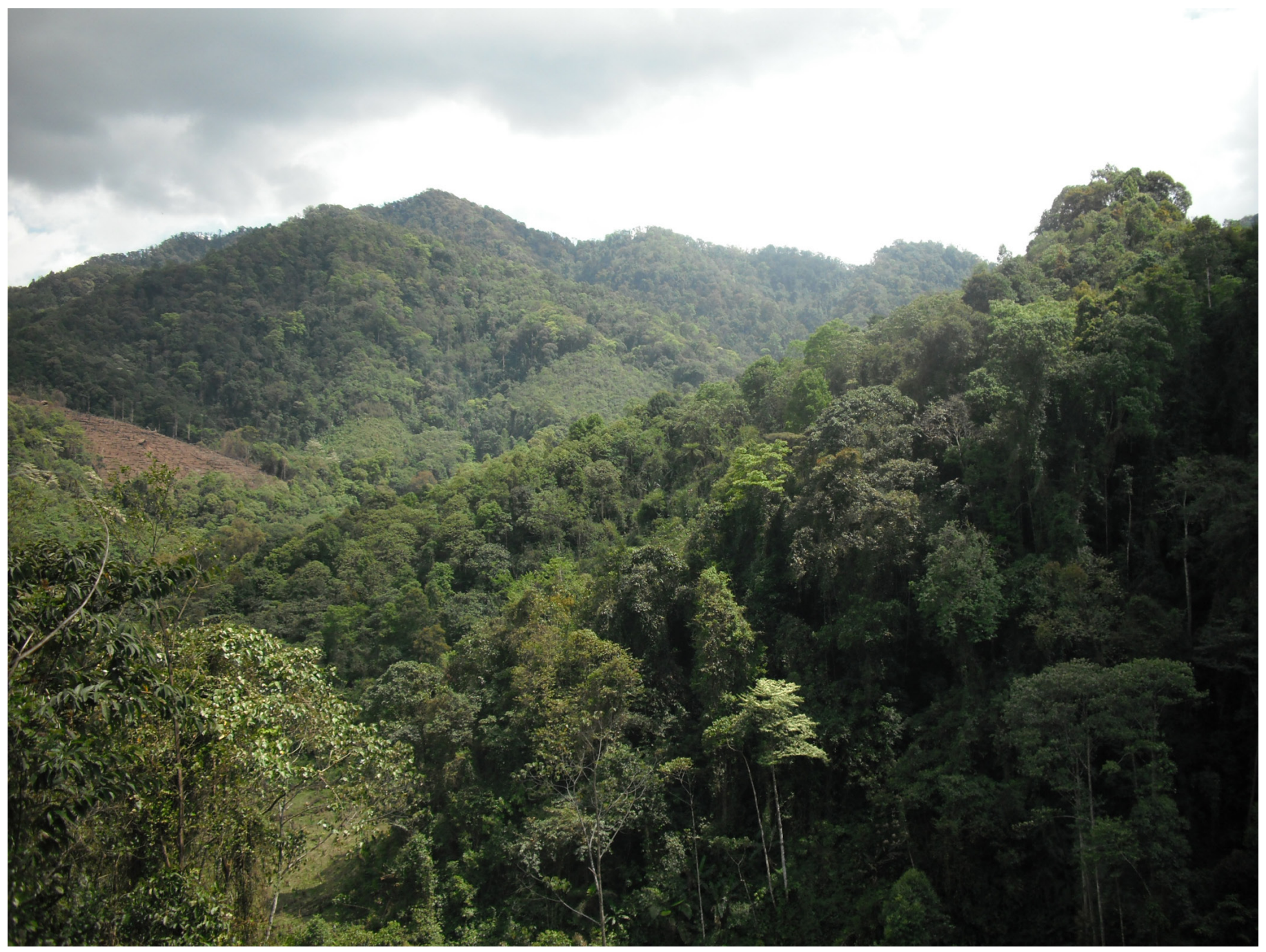

Fig. 7. Subtropical forest habitat of the Medo Pit Viper (Viridovipera medoensis) in Papum Pare District, Arunachal Pradesh.

approximately $400 \mathrm{~km}$ within Arunachal Pradesh (Fig. 1). Medo Pit Vipers have a patchy distribution and the paucity of known localities across India, Myanmar, and China highlights the need for more surveys across the species' entire range. Further investigations also are needed to decipher the species' population ecology and natural history to help assess its conservation status.

\section{Acknowledgements}

We thank The Arunachal Pradesh Forest Department for logistical support in the region and the people of Leporiang for hospitality and assistance. We thank Nabam Radhe, Mallo Taka, Nathung, Kampu, and Ara of Leporiang Village for the essential local knowledge that made our work possible. We thank Anant Deshwal for creating the maps, David Willis of the British Herpetological Society, Gernot Vogel, Kraig Adler, and Ishan Agarwal for help in sourcing literature. Finally, we thank the participants of the two expeditions for their contributions to the project.

\section{Literature Cited}

David, P., N. Vidal, and O.S.G. Pauwels. 2001a. A morphological study of Stejneger's Pitviper Trimeresurus stejnegeri (Serpentes, Viperidae, Crotalinae), with the description of a new species from Thailand. Russian Journal of Herpetology 8:205-222.

David, P., A. Captain, and B.B. Bhatt. 2001b. On the occurrence of Trimeresurus medoensis Djao in Djao and Jiang, 1977 (Serpentes, Viperidae, Crotalinae) in India, with a redescription of this species and notes on its biology. Hamadryad 26:210-226.

Djao, E-M. and Y-M. Jiang. 1977. A survey of reptiles in Xizang Autonomous Region, with faunal analysis and descriptions of new forms. Acta Zoologica Sinica 23:64-71.

Leviton, A.E., G.O.U. Wogan, M.S. Koo, G.R. Zug, R.S. Lucas, and J.V. Vindum. 2003. The dangerously venomous snakes of Myanmar illustrated checklist with keys. Proceedings of California Academy of Science. 54:407-462.

Malhotra, A. and R.S. Thorpe. 1997. New perspectives on the evolution of south-east Asian pit vipers (genus Trimeresurus) from molecular studies, pp 115-128. In: R.S. Thorpe, W. Wüster, and A. Malhotra (eds.), Venomous Snakes: Ecology, Evolution and Snakebite. Symposium Zoological Society London. London.

Malhotra, A. and R.S. Thorpe. 2000. A phylogeny of the Trimeresurus group of pit vipers: New evidence from a mitochondrial gene tree. Molecular Phylogenetics and Evolution 16:199-211.

Malhotra, A. and R.S. Thorpe. 2004. A phylogeny of four mitochondrial gene 


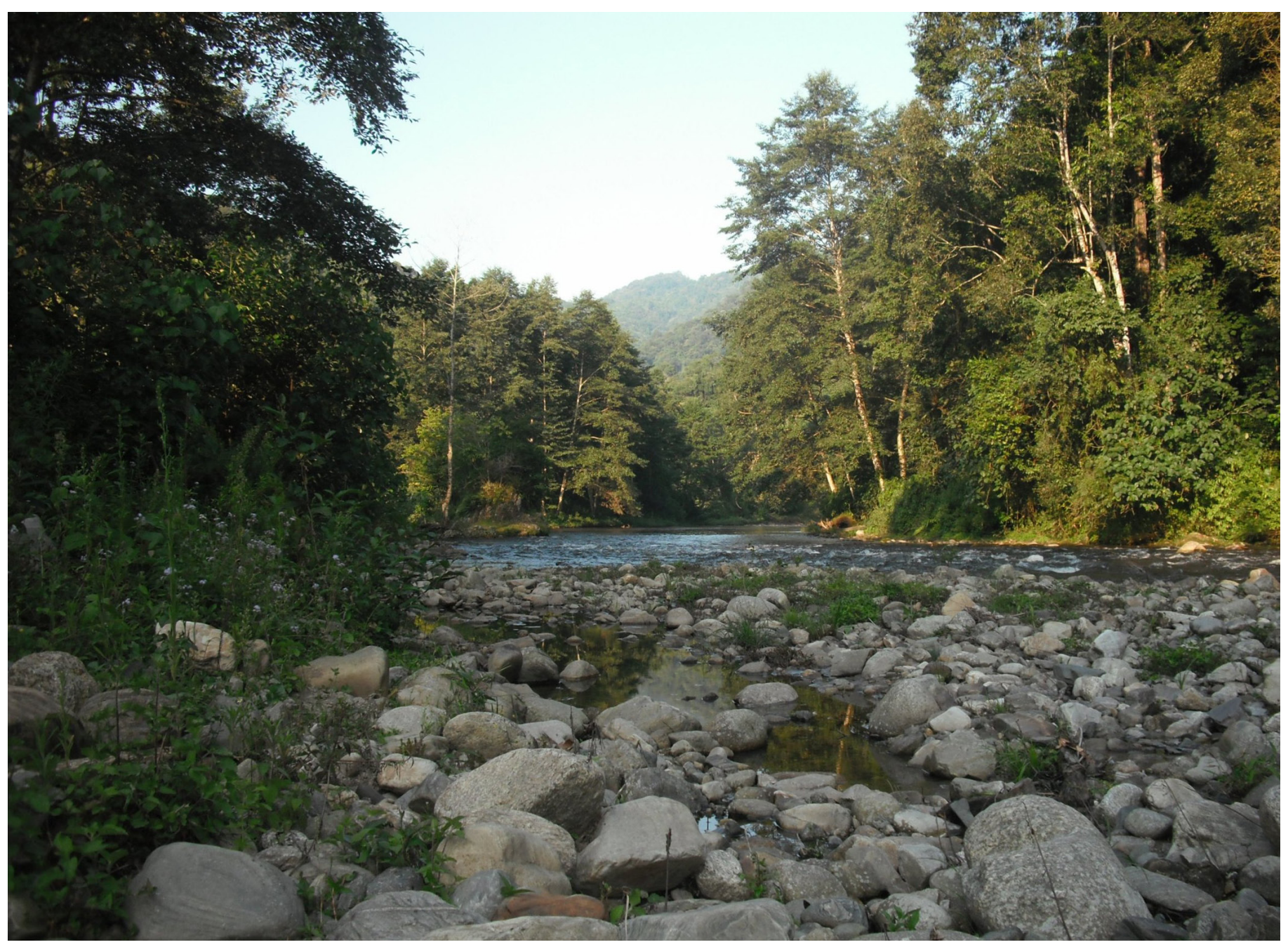

Fig. 8. The Papum Pare River in Papum Pare District, Arunachal Pradesh.

regions suggest a revised taxonomy for Asian pitvipers (Trimeresurus and Ovophis). Molecular Phylogenetics and Evolution 32:83-100.

McDiarmid, R.W., M.S. Foster, C. Guyer, J.W. Gibbons, and N. Chernoff. 2012. Reptile Biodiversity: Standard Methods for Inventory and Monitoring. University of California Press, Berkeley.

Peng, G. and Z. Fuji. 2000. Comparative studies on hemipenes of four species of Trimeresurus (sensu stricto) (Serpentes: Crotalinae). Amphibia-Reptilia 22:113-117.

Tu, M-C., H-Y. Wang, M-P. Tsai, M. Toda, W-J. Lee, F-J. Zhang, and H. Ota.
2000. Phylogeny, taxonomy and biogeography of the Oriental pitvipers of the genus Trimeresurus (Reptilia: Viperidae: Crotalinae): A molecular perspective. Zoological Science 17:1147-1157.

Whitaker, R. and A. Captain. 2004. Snakes of India: The Field Guide. Draco Books, Chennai, India.

Zhao, E-M. and K. Adler. 1993. Herpetofauna of China. Contributions to Herpetology, volume 10. Society for the Study of Amphibians and Reptiles. Salt Lake City, Utah.

Zhou, Z. and D.-Q. Rao. 2012. Viridovipera medoensis. IUCN 2012. IUCN Red List of Threatened Species. Version 2012.2. <www.iucnredlist.org>. 